American Journal of Plant Nutrition and Fertilization Technology 2 (1): 27-31, 2012

ISSN 1793-9445 / DOI: 10.3923/ajpnft.2012.27.31

(C) 2012 Academic Journals Inc.

\title{
The Role of Seed Provenance in the Growth and Nutrient Status of Black Locust (Robinia pseudoacacia L.)
}

\author{
${ }^{1}$ Alireza Moshki, ${ }^{2} \mathrm{~S}$. Mohammad Hodjati, ${ }^{3}$ Neda Bakhshandeh and \\ ${ }^{1}$ Norbert P. Lamersdorf \\ ${ }^{1}$ Büsgen-Institut, Soil Science of Temperate and Boreal Ecosystems, Faculty of Forest Sciences and Forest \\ Ecology, University of Goettingen, Büsgenweg 2, 37077, Goettingen, Germany \\ ${ }^{2}$ Department of Forestry, Faculty of Natural Resources, Sari Agricultural Sciences and Natural Resources \\ University, Sari, Iran \\ ${ }^{3}$ Biology Group, Basic Sciences faculty, Islamic Azad University, Izeh, Iran
}

Corresponding Author: Alireza Moshki, Büsgen-Institut, Soil Science of Temperate and Boreal Ecosystems, Faculty of Forest Sciences and Forest Ecology, University of Goettingen, Büsgenweg 2, 37077, Goettingen, Germany

\begin{abstract}
Black locust (Robinia pseudoacacia) has worldwide economic and ecological importance and cultivated widely at the rate of three million hectare globally. A greenhouse experiment was carried out to investigate the role of seed provenance in growth and nutrient status of Robinia. Seeds from different geographical locations were planted in the same ecological conditions. After six months, all Robinia trees were harvested and separated into leaves, stems and roots. Element concentrations of $\mathrm{P}, \mathrm{S}, \mathrm{K}, \mathrm{Ca}, \mathrm{Mg}, \mathrm{Fe}, \mathrm{Al}, \mathrm{Mn}$ and $\mathrm{K}$ in organic materials (leaves, stems and roots samples) were measured by ICP-AES. A significant difference was detected among seeds provenances of Robinia. regarding height $(160-240 \mathrm{~cm})$ and diameter $(4.2-6.8 \mathrm{~mm})$. Different Robinia seed provenances showed significant different concentrations of potassium $(\mathrm{K})$ in leaves and calcium $(\mathrm{Ca})$ in stems while no significant differences was observed in terms of other investigated nutrients.
\end{abstract}

Key words: Black locust, Robinia pseudoacacia, provenance, nutrient status

\section{INTRODUCTION}

Black locust (Robinia pseudoacacia L.), native to North America (Barrette et al., 1990), is one of the most effective nitrogen fixing tree species in the world (Olesniewicz and Thomas, 1999). It has global economic and ecological importance and planted widely in temperate North America, Europe and Asia at the rate of three million hectare globally (Hanover et al., 1991).

The nutritional status of plants is directly related to their growth and productivity (Mengel and Kirkby, 2001). It is strongly influenced by some key parameters like the nutrient availability in soils, the genetically nutrient uptake potential and some environmental boundary conditions like soil fertility, elevation, slope and climate conditions (Wu et al., 2007; Van den Driessche, 1974).

According to the European community definition, provenance is the place where the stands of trees (whether native or not) are growing (Ford-Robertson, 1971). The effects of seed source on the physiological and phonological characteristics of trees were investigated in several studies (Oleksyn et al., 1992; Varelides et al., 2001; Eysteinsson et al., 2009). Also, it is proved that the nitrogen fixation ability of Robinia pseudoacacia, Acacia nilotica and Faidherbia albida is affected by seed provenance (Moshki and Lamersdorf, 2011a; Beniwal et al., 1995; Gueye et al., 1997). 
Moshki and Lamersdorf (2011b) showed that the soil properties have significant role in nutrient status of Robinia in arid and semi-arid regions of Iran. However, so far, no study was carried out to investigate the seed provenance effect on nutrients status of Robinia.

\section{MATERIALS AND METHODS}

Greenhouse experiment: Seeds provenances of Robinia were selected in Iran and Hungary. Selected areas show different environmental conditions in terms of amount of precipitation, average temperature and elevation (Table 1). The greenhouse experiment was conducted in Göttingen, Germany (51 $33^{\prime} \mathrm{N}$ and $9^{\circ} 57^{\prime} \mathrm{E}$ at elevation of $205 \mathrm{~m}$ ). Collected seeds were scarified using abrasive paper, were soaked in water over the night and planted. After three weeks preliminary growth, they were transplanted into pots containing commercial potting soil (Table 2). The temperature of greenhouse was adjusted constantly on $18^{\circ} \mathrm{C}$. The photoperiod was eight hours per day. All of plants received same amount of water two times per week. The height and diameter of each plant were measured after three months and continued at an interval of one month up to end of experiment (six months). A Completely Randomized Design (CRD) was used, consisting of four treatments of Robinia seed sources, one for each collection provenance (i.e., Hosszupalyi, Karaj, Sanandaj and Semnan). We replicated each treatment six times.

Sampling and chemical analysis: After six months, Robinia trees were harvested and separated into leaves, stems and roots. Samples were washed with distilled water, dried at $60^{\circ} \mathrm{C}$ for $48 \mathrm{~h}$, weighted and ground. Element concentrations of $\mathrm{P}, \mathrm{S}, \mathrm{K}, \mathrm{Ca}, \mathrm{Mg}, \mathrm{Fe}, \mathrm{Al}, \mathrm{Mn}$ and $\mathrm{K}$ in organic materials (leaves, stems and roots samples) were measured by ICP-AES (Spectroflame, Spectro Analytical Instruments, Kleve, Germany) after pressure digestion of samples with 65\% of concentrated $\mathrm{HNO}_{3}$ (Heinrichs, 1989).

Statistical analyses: Data were analysed using one-way ANOVA, followed by mean comparisons using the Duncan test at $95 \%$ confidence level test to identify the statistical differences of measured parameters among Robinia seed origins. The STATISTICA software version 7.0 was used for statistical analysis.

Table 1: Locations of seeds collecting areas

\begin{tabular}{|c|c|c|c|c|c|c|c|}
\hline Origin of & Country/city) & Elevation (m) & $\begin{array}{l}\text { Latitude } \\
\text { (N) }\end{array}$ & $\begin{array}{l}\text { Longitude } \\
\text { (E) }\end{array}$ & $\begin{array}{l}\text { Annual mean } \\
\text { temperature }\left({ }^{\circ} \mathrm{C}\right)\end{array}$ & $\begin{array}{l}\text { Annual } \\
\text { precipitation }(\mathrm{mm})\end{array}$ & $\begin{array}{l}\text { Period of } \\
\text { sunshine } \\
\text { (h/year) }\end{array}$ \\
\hline \multirow[t]{2}{*}{ Iran } & Semnan & 1117 & $35^{\circ} 36^{\prime}$ & $53^{\circ} 30^{\prime}$ & 18.3 & 141 & 3018 \\
\hline & Karaj & 1275 & $35^{\circ} 44^{\prime}$ & $51^{\circ} 10^{\prime}$ & 15.8 & 244 & 2952 \\
\hline \multirow[t]{2}{*}{ Hungary } & Sanandaj & 1397 & $35^{\circ} 14^{\prime}$ & $47^{\circ} 00^{\prime}$ & 14.2 & 459 & 2829 \\
\hline & Hosszupalyi & 105 & $47^{\circ} 24^{\prime}$ & $21^{\circ} 45^{\prime}$ & 10.1 & 567 & 1982 \\
\hline
\end{tabular}

Table 2: Soil properties used for greenhouse experiment

\begin{tabular}{ccccccc}
\hline Soil properties & $\mathrm{pH}\left(\mathrm{CaCl}_{2}\right)$ & $(\mathrm{KCl})\left(\mathrm{g} \mathrm{L}^{-1}\right)$ & $(\mathrm{OM}) \%$ & $\mathrm{~N}\left(\mathrm{mg} \mathrm{L}^{-1}\right)$ & $\mathrm{P}_{2} \mathrm{O}_{5}\left(\mathrm{mg} \mathrm{L}^{-1}\right)$ & $\mathrm{K}_{2} \mathrm{O}\left(\mathrm{mg} \mathrm{L}^{-1}\right)$ \\
\hline 5.9 & 2.0 & 35 & 300 & 240 & 350 \\
\hline
\end{tabular}

OM: Organic matter 


\section{RESULTS AND DISCUSSION}

A significant difference was found among Robinia seed origins in terms of height (160-240 cm, Fig. 1) and diameter (4.2-6.8 mm, Fig. 1). Through continuous measurements, Hosszupalyi always had significantly higher values and Semnan had lower values than other seed provenances regarding height and diameter growth. However, no significant difference was found between two other provenances regarding these parameters. Furthermore, Robinia seed origins showed different concentrations of potassium (K) in leaves and calcium (Ca) in stems whereas they uptake nutrients from the same pool. However, no significant difference was detected through comparison of other nutrient contents in different Robinia provenances (Table 3).
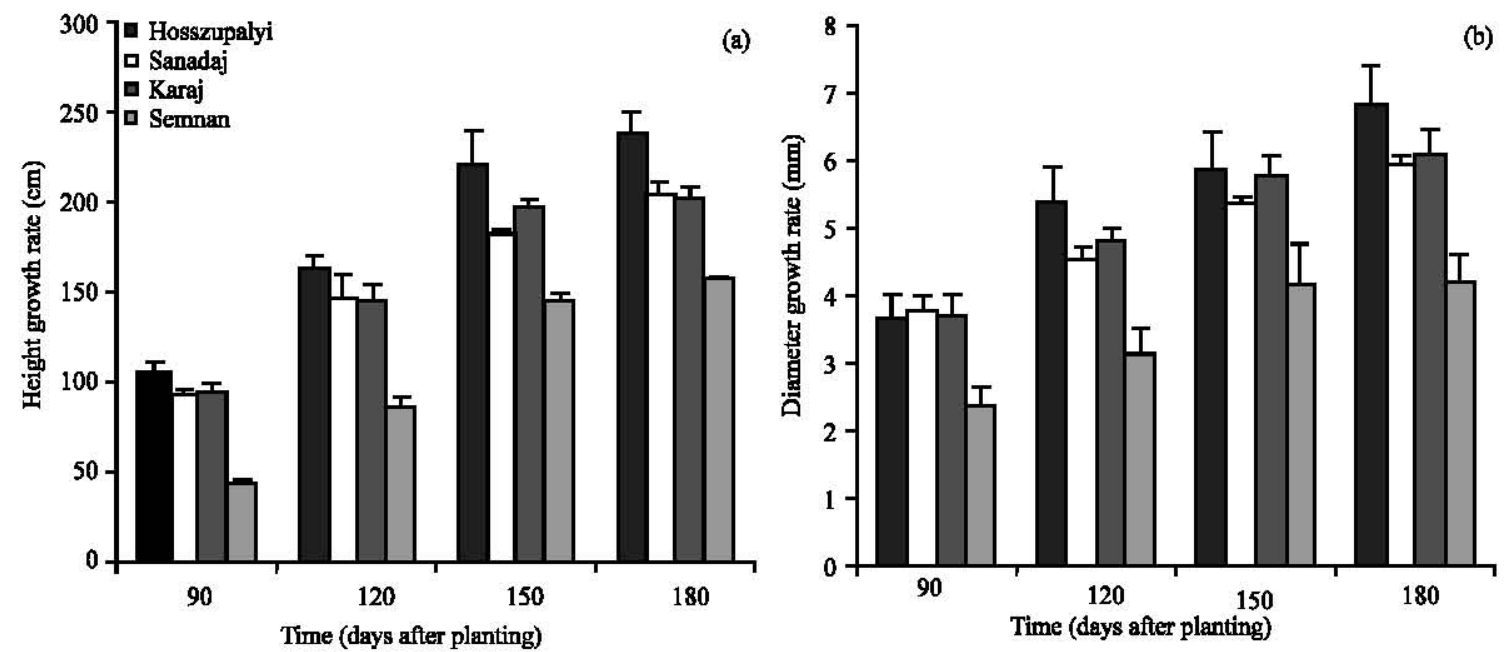

Fig. 1: Mean (SD) of height and diameter growth rate of Robinia in different provenances during growing period

Table 3: Nutrients content in leaves and stem of Robinia in different study sites

\begin{tabular}{|c|c|c|c|c|c|c|c|c|c|c|}
\hline \multirow[b]{2}{*}{$\begin{array}{l}\text { Plant } \\
\text { tissue }\end{array}$} & \multirow[b]{2}{*}{ Provenances } & \multicolumn{9}{|c|}{ Nutrients $\left(\mathrm{mg} \mathrm{g}^{-1}\right)$} \\
\hline & & $\mathrm{P}$ & $\mathrm{S}$ & $\mathrm{Na}$ & $\mathrm{K}$ & $\mathrm{Ca}$ & $\mathrm{Mg}$ & $\mathrm{Mn}$ & $\mathrm{Fe}$ & $\mathrm{Al}$ \\
\hline \multirow[t]{4}{*}{ Leaf } & Semnan & $4.48 \pm 0.86^{\mathrm{a}}$ & $2.77 \pm 0.44^{\mathrm{a}}$ & $0.05 \pm 0.00^{\mathrm{a}}$ & $28.61 \pm 2.73^{b}$ & $25.09 \pm 1.72^{\mathrm{a}}$ & $3.53 \pm 0.87^{\mathrm{a}}$ & $0.10 \pm 0.00^{\mathrm{a}}$ & $0.15 \pm 0.01^{\mathrm{a}}$ & $0.09 \pm 0.01^{\mathrm{a}}$ \\
\hline & Sanandaj & $4.62 \pm 0.77^{\mathrm{a}}$ & $2.51 \pm 0.29^{\mathrm{a}}$ & $0.05 \pm 0.00^{\mathrm{s}}$ & $24.76 \pm 1.68^{\mathrm{ab}}$ & $24.75 \pm 3.66^{\mathrm{a}}$ & $2.63 \pm 0.32^{\mathrm{a}}$ & $0.13 \pm 0.01^{\mathrm{a}}$ & $0.13 \pm 0.01^{\mathrm{a}}$ & $0.07 \pm 0.00^{\mathrm{a}}$ \\
\hline & Karaj & $4.70 \pm 1.34^{\mathrm{a}}$ & $2.64 \pm 0.32^{\mathrm{a}}$ & $0.06 \pm 0.00^{\mathrm{a}}$ & $24.03 \pm 1.44^{a b}$ & $25.76 \pm 4.69^{\mathrm{a}}$ & $2.55 \pm 0.82^{\mathrm{a}}$ & $0.13 \pm 0.04^{\mathrm{a}}$ & $0.16 \pm 0.02^{\mathrm{a}}$ & $0.09 \pm 0.01^{\mathrm{a}}$ \\
\hline & Hosszupalyi & $4.46 \pm 0.54^{\mathrm{a}}$ & $3.05 \pm 0.74^{\mathrm{a}}$ & $0.06 \pm 0.01^{\mathrm{a}}$ & $21.08 \pm 1.16^{\mathrm{a}}$ & $25.56 \pm 8.30^{\mathrm{a}}$ & $2.82 \pm 0.76^{\mathrm{a}}$ & $0.12 \pm 0.01^{\mathrm{a}}$ & $0.17 \pm 0.04^{\mathrm{a}}$ & $0.08 \pm 0.00^{\mathrm{a}}$ \\
\hline \multirow[t]{4}{*}{ Stem } & Semnan & $3.13 \pm 0.80^{\mathrm{a}}$ & $1.25 \pm 0.12^{\mathrm{a}}$ & $0.04 \pm 0.01^{\mathrm{a}}$ & $11.17 \pm 1.29^{\mathrm{a}}$ & $5.02 \pm 0.56^{\mathrm{a}}$ & $0.86 \pm 0.11^{\mathrm{a}}$ & $0.00 \pm 0.00$ & $0.03 \pm 0.00^{\mathrm{s}}$ & $0.00 \pm 0.00$ \\
\hline & Sanandaj & $2.68 \pm 0.34^{a}$ & $1.38 \pm 0.17^{\mathrm{a}}$ & $0.05 \pm 0.01^{\mathrm{a}}$ & $10.90 \pm 0.94^{\mathrm{a}}$ & $5.27 \pm 0.43^{\mathrm{ab}}$ & $1.01 \pm 0.05^{\mathrm{a}}$ & $0.01 \pm 0.00^{\mathrm{s}}$ & $0.06 \pm 0.03^{b}$ & $0.01 \pm 0.01^{\mathrm{a}}$ \\
\hline & Karaj & $2.89 \pm 0.16^{\mathrm{a}}$ & $1.14 \pm 0.18^{\mathrm{a}}$ & $0.05 \pm 0.00^{\mathrm{a}}$ & $9.95 \pm 1.08^{\mathrm{a}}$ & $6.17 \pm 1.12^{\mathrm{ab}}$ & $0.88 \pm 0.14^{\mathrm{a}}$ & $0.01 \pm 0.00^{\mathrm{a}}$ & $0.04 \pm 0.00^{\mathrm{a}}$ & $0.00 \pm 0.00$ \\
\hline & Hosszupalyi & $2.85 \pm 0.30^{\mathrm{a}}$ & $1.35 \pm 0.07^{\mathrm{a}}$ & $0.05 \pm 0.02^{\mathrm{a}}$ & $10.22 \pm 0.36^{\mathrm{a}}$ & $6.84 \pm 0.87^{b}$ & $0.85 \pm 0.03^{\mathrm{a}}$ & $0.01 \pm 0.00^{\mathrm{a}}$ & $0.04 \pm 0.00^{\mathrm{a}}$ & $0.01 \pm 0.00^{\mathrm{a}}$ \\
\hline \multirow[t]{4}{*}{ Root } & Semnan & $5.33 \pm 0.64^{\mathrm{a}}$ & $4.01 \pm 0.40^{\mathrm{a}}$ & $1.05 \pm 0.25^{\mathrm{a}}$ & $22.73 \pm 2.76^{\mathrm{a}}$ & $4.77 \pm 0.68^{\mathrm{a}}$ & $2.83 \pm 0.56^{\mathrm{a}}$ & $0.12 \pm 0.05^{\mathrm{a}}$ & $0.57 \pm 0.20^{\mathrm{a}}$ & $0.60 \pm 0.13^{\mathrm{a}}$ \\
\hline & Sanandaj & $5.48 \pm 0.32^{\mathrm{a}}$ & $3.60 \pm 0.79^{\mathrm{a}}$ & $0.68 \pm 0.21^{\mathrm{a}}$ & $21.37 \pm 1.56^{\mathrm{a}}$ & $3.76 \pm 0.26^{\mathrm{a}}$ & $3.27 \pm 0.72^{\mathrm{a}}$ & $0.16 \pm 0.05^{\mathrm{a}}$ & $0.48 \pm 0.20^{\mathrm{a}}$ & $0.54 \pm 0.17^{\mathrm{a}}$ \\
\hline & Karaj & $6.58 \pm 0.79^{\mathrm{a}}$ & $4.13 \pm 0.92^{\mathrm{a}}$ & $1.20 \pm 0.21^{\mathrm{a}}$ & $20.48 \pm 0.31^{\mathrm{a}}$ & $4.19 \pm 0.91^{\mathrm{a}}$ & $3.30 \pm 0.52^{\mathrm{a}}$ & $0.08 \pm 0.02^{\mathrm{a}}$ & $0.33 \pm 0.08^{\mathrm{a}}$ & $0.63 \pm 0.30^{\mathrm{a}}$ \\
\hline & Hosszupalyi & $4.48 \pm 0.92^{\mathrm{a}}$ & $3.93 \pm 0.70^{\mathrm{a}}$ & $1.15 \pm 0.67^{\mathrm{a}}$ & $19.97 \pm 0.50^{\mathrm{a}}$ & $4.61 \pm 0.92^{\mathrm{a}}$ & $3.26 \pm 0.64^{\mathrm{a}}$ & $0.12 \pm 0.05^{\mathrm{a}}$ & $0.41 \pm 0.02^{\mathrm{a}}$ & $0.64 \pm 0.06^{\mathrm{a}}$ \\
\hline
\end{tabular}

Values are as Mean \pm SD. Different letters in same columns indicate significant $(p<0.05)$ differences among provenances 
By supporting the results of this study, the seed provenance significantly affect growth of Robinia while it affects nutrient status of Robinia weakly. Only $\mathrm{K}$ in leaves and Ca in stems were different amongst different provenances of Robinia.

Three of four provenances used in this study are originated from the arid and semi-arid regions of Iran. These regions are characterised with salt and water stress problems that limit growth of the plants. Both of the Ca and K have significant role in plant growth and physiological functions, where environmental factors such as salt and drought stress limit growth of the plants ( $\mathrm{Hu}$ and Schmidhalter, 2005; Cakmak, 2005). The growth of the Robinia is varied significantly amongst different Robinia seed provenances. Therefore, it is expected that the concentrations of $\mathrm{Ca}$ and $\mathrm{K}$ are varied amongst Robinia seed provenances as well because of the role of these elements in growth of Robinia.

The seed provenance effect on nutrient status of plants was reported also for Pinus sylvestris (Gerhold, 1959; Steinbeck, 1966; Raitio and Sarjala, 2000) and Pinus nigra (Oleksyn et al., 1987).

As shown in this study, the seed origin has significant role in growth of Robinia and affects softly the nutrient status of Robinia. Therefore it should be taken into account as an important factor to enhance success of plantation projects. Hence one testing phase of available seeds provenances is strongly recommended before decision for planting of Robinia in any given area.

\section{ACKNOWLEDGEMENTS}

We are grateful to German Academic Exchange Service (DAAD) for funding this project.

\section{REFERENCES}

Barrette, R.P., T. Mebrahtu and J.W. Hanover, 1990. Black Locust: A Multipurpose Tree Species for Temperate Climates. In: Advances in New Crops, Janick J. and J. Simon (Eds.). Timber Press, Portland, pp: 278-283.

Beniwal, R.S, O.P. Toky and P.K. Sharma, 1995. Genetic variability in symbiotic nitrogen-fixation between provenances of Acacia nilotica (L) Willd. ex Del. Genet. Resour. Crop Evol., 42: 7-13.

Cakmak, I., 2005. The role of potassium in alleviating detrimental effects of abiotic stresses in plants. J. Plant Nutr. Soil Sci., 168: 521-530.

Eysteinsson, T., L. Karlman, A. Fries, O. Martinsson and B. Skulason, 2009. Variation in spring and autumn frost tolerance among provenances of Russian larches (Larix Mill.). Scand. J. Forest Res., 24: 100-110.

Ford-Robertson, F.C., 1971. Terminology of Forest Science, Technology Practice and Products. Society of American Foresters, Washington.

Gerhold, H.D., 1959. Seasonal variation of chloroplast pigments and nutrient elements in the needles of geographic races of Scotch pine. Silvae Genet., 8: 113-123.

Gueye, M., I. Ndoye, M. Dianda, S.K.A. Danso and B. Dreyfus, 1997. Active $\mathrm{N}_{2}$ fixation in several Faidherbia albida provenances. Arid Soil Res. Rehabil., 11: 63-70.

Hanover, J.W., T. Mebrathu and P. Bloese, 1991. Genetic improvement of black locust: A prime agroforestry species. Forestry Chronicle, 67: 227-231.

Heinrichs, H., 1989. Aufschlussverfahren in der analytischen. Geochemie (Teil 1). Labor Praxis, 12/89: 1140-1146. 
Hu, Y. and U. Schmidhalter, 2005. Drought and salinity: A comparison of their effects on mineral nutrition of plants. J. Plant Nutr. Soil Sci., 168: 541-549.

Mengel, K. and E.A. Kirkby, 2001. Principles of Plant Nutrition. 5th Edn., Kluwer Academic Publishers, Dordrecht, Boston, London, ISBN: 1402000081.

Moshki, A. and N.P. Lamersdorf, 2011a. Growth and nutrient status of introduced black locust (Robinia pseudoacacia L.) afforestation in arid and semi arid areas of Iran. Res. J. Environ. Sci., 5: 259-268.

Moshki, A. and N.P. Lamersdorf, 2011b. Symbiotic nitrogen fixation in black locust (Robinia pseudoacacia L.) seedlings from four seed sources. J. For. Res., 22: 689-692.

Oleksyn, J., K. Oleksynowa, E. Kozlowska and L. Rachwal, 1987. Mineral content and the sensitivity of black pine (Pinus nigra) of various provenances to industrial air pollution. For. Ecol. Manag., 21: 237-247.

Oleksyn, J., W. Chalupka, M.G. Tjoelker and P.B. Reich, 1992. Geographic origin of Pinus sylvestris populations influences the effects of air pollution on flowering and growth. Water Air Soil Pollut., 62: 201-212.

Olesniewicz, K.S. and R.B. Thomas, 1999. Effects of mycorrhizal colonization on biomass production and nitrogen fixation of black locust (Robinia pseudoacacia) seedlings grown under elevated atmospheric carbon dioxide. New Phytol., 142: 133-140.

Raitio, H. and T. Sarjala, 2000. Effect of provenance on free amino acid and chemical composition of Scots pine needles. Plant Soil., 221: 231-238.

Steinbeck, K., 1966. Site, height and mineral nutrient content relations of Scotch pine provenances. Silvae Genet., 15: 42-50.

Van den Driessche, R., 1974. Prediction of mineral nutrient status of trees by foliar analysis. Bot. Rev., 40: 347-394.

Varelides, C., G. Brofas and Y. Varelides, 2001. Provenance variation in Pinus nigra at three sites in Northern Greece. Ann. Forest Sci., 58: 893-900.

Wu, C.C., C.C. Tsui, C.F. Hseih, V.B. Asio and Z.S. Chen, 2007. Mineral nutrient status of tree species in relation to environmental factors in the subtropical rain forest of Taiwan. For. Ecol. Manage., 239: 81-91. 